\title{
Do Banking Sector Reforms Drive Economic Growth in Nigeria
}

\author{
Ikubor Ofili Jude \\ Department of Economics, Ambrose Alli University, Ekpoma, Nigeria
}

Email address:

judeikubor046@gmail.com

\section{To cite this article:}

Ikubor Ofili Jude. Do Banking Sector Reforms Drive Economic Growth in Nigeria. International Journal of Business and Economics Research. Vol. 8, No. 5, 2019, pp. 273-285. doi: 10.11648/j.ijber.20190805.14

Received: May 26, 2019; Accepted: July 10, 2019; Published: August 12, 2019

\begin{abstract}
Banking sector reforms is the deliberate policy measures adopted by the monetary authority to promote the safety, soundness, reliability and stability of the sector, in order to be able to deliver the expected goods by improving the economy. It is against this background the investigates that impact of bank sector reforms on Nigeria's economics growth for the period which spanned from 1970 to 2014 using ARDL analysis. The period study was disaggregated into pre bank reforms period (1970-1985), reforms period (1986-2014) and pool period (1970-2014). Real Gross domestic product (GDP) was used as a proxy for economic growth regressed on some bank performance variables such as ratio of narrow money to broad money, loan deposit ratio, commercial bank credit to the private sector, cash reserve ratio and interest rate. The study found that the bank reformed has not impacted on the growth of the Nigerian economy. The study recommend that the government should ensure strict regulatory measures through the use of its monetary policies to regulate the banking sector and the Central Bank of Nigeria should continue with its banking sector reforms and encourage substantial credit allocation to the prioritized private sector.
\end{abstract}

Keyword: Bank Reform, GDP, Loan Deposit Ratio, Credit to Private Sector, Cash Reserve Ratio

\section{Introduction}

The theory of financial reform provides a useful account of how a smooth-functioning financial market provides high and sustained economic growth. [1] Fundamentally, financial reform or banking reform is simply the process of moving towards market-determined rate of interest as well as marketdetermined prices as opposed to government-regulated rate of interest (known as interest rate ceiling) [2] which may have a significant effect in enhancing growth by promoting a more efficient allocation of resources, encouraging a faster accumulation of physical and human capital and technological progress, and reducing production costs relating to transaction, information and monitoring. Building on the previous explanation, reforms in the financial sector have on driving factors that turned banking into more competitive environment. Interest for instance, Nigerian economy has embarked upon several financial reforms since adoption of structural adjustment programme (SAP) in the mid 80 s such as banking sector deregulation, flexible exchange rate including facilitating the new entry of domestic and foreign banks, the gradual deregulation of lending and deposit interest rates, facilitating the use of credit and debit cards, updating payment technologies like ATM machines and electronic transfer of deposits, expanding a variety of internet banking services like e-banking and mobile banking technology, enhancing telecommunications infrastructure, supporting their financial sector with such measures like tax-free environment. However, these various reforms and innovations are expected to stimulate the performance of Nigerian Economy.

According to the study [3] the existence and evolution of vibrant financial institutions and markets constitute an important factor in the process of economic growth and development in a modern economy while some scholars note that the following ways are some of the ways the banking system assists in promoting economic growth and development such improving the efficiency of resource immobilization by pooling individual savings, increasing the proportion of societal resources devoted to interest yielding assets and long- term investment which in turn facilitate economic growth, reducing the risk faced by firms in their 
production process by providing liquidity and also a veritable platform for an effective monetary policy implementation; thereby enhancing the effective management of the economy. [4] observe that the banking system has been functioning as one of the channels through which government carries out its policy of stabilizing the economy. Through the manipulation of some key variables such as interest rate and the quantum of credit, government will able to influence borrowing and spending within the economy. These in turn will positively affect employment, production and prices for goods and services by achieving the desire objectives. In recognition of the important roles of banking sector in driving economic growth and development, the Nigerian government and monetary authority embarked on five distinct phases of banking sector reforms.

Banking sector reforms is the deliberate policy measures adopted by the monetary authority to promote the safety, soundness, reliability and stability of the sector, in order to be able to deliver the expected "goods" by improving the economy. Undoubtedly and unarguably, the banking sector has undergone remarkable changes in terms of the number of institution, ownership structure depth and breadth of the financial market, money supply, credit to private sector and financial deepening. This has been achievable as a result of the various financial sectors reforms carried out in Nigeria, particularly in the banking sector. The study [5] asserts that banking sector is the most vibrant and dominant sector in the Nigerian financial industry because, whatever difficulties it passes through affects the entire economy. In July, 2004, the Central Bank of Nigeria launched a 13 point agenda that was aimed to develop bigger banks with stronger balance sheets, ensuring safe and sound banking practice and enhancing effective regulatory capacity to supervise the industry. According to the study [6] the key element of the reform program was the increase in minimum capital base of banks from N2billion to N25billion by December, 2005. According to him the reforms program was driven by the following factors: Nigeria banks were small, and depended on government or public sectors deposits and unable to meet the economy's funding needs and banking penetration was low and retail offerings were limited. For example deposits in the hands of small business and individuals at $80 \%$ of the total currency in circulation, because of this, the industry was fragmented and many banks operated as fringe players. Consequently, corporate governance was poor as a result of insider abuse and sharp practices by directors and related parties that were rampant.

Experience has shown that inadequate reform leads to unsound banking system, weakens efficient credit allocation, distorts the structure of interest rate, disrupt monetary policy, and impose significant financial cost, with adverse consequence on the stabilization of the economy. Where the majority of banks are weak and unhealthy, that will impair the ability of the industry to lubricate economic growth [7]. In Nigeria [8], shows that $\mathrm{CBN}$ reform has changed the market structure of the Nigerian banking sector, increased the efficiency and reliability of the banks, created opportunities for financial institutions and market participants, and raised their intermediation potentials but studies [9] shows that while some reforms are beneficial and improved the Nigerian economy others left it worse than it were before such reforms. The study [9] posited that the 2004 consolidation exercise is one of those failed reforms. The study [10] disagree with the study [9] as he found that the intermediation activities of an average bank improved significantly in 2006. Therefore this study aims to examine the effect of bank reformed on Nigeria economic growth.

However despite the enormous bank reforms in Nigeria and the theoretical assumption that it contribute to growth and development of the economy but the Nigerian economy has been characterized by low manufacturing capacity utilization, high level of inflation, heavy debt burden, high unemployment rate, high level of income inequality, poverty to mention a few. Furthermore, a quick look at some basic economic indicators confirms this conclusion. The output growth rate as measured by changes in the real Gross Domestic Product (GDP) has been very volatile. For example, the economy recorded negative growth rate from 1981 - 1984. However, from 1985 to 1990, an average growth rate of 6.3 percent was recorded. Thereafter, economic performance deteriorated with GDP declining to barely 1.0 percent by 1994 . Between 1999 and 2002, the GDP growth rate has averaged 3.5, 2003 to 2006, GDP rose to 5.8 percent and $2007-2009$, an average growth rate of 6.5 percent was recorded while between 2010 to 2014 recorded an average of 5.4 percent [11]. Therefore, the question whether the reforms programme achieved its ultimate objectives remains an empirical question which this study intends to provide an insight. It is to this end that this research work seeks to measure the impact of banking sector reforms on economic growth in Nigeria. Also the study will contribute to knowledge by disintegrating the period of study into pre bank reforms, bank reforms and the pool period compared to other study which use dummy variable for bank reformed period. The study also employed ARDL econometric techniques compared to like these studies [1217] which employed the Ordinary Least Squares and Error Correction Method. Therefore, the main objective of the study is to examine the impact of the banking sector reforms on Nigeria economic growth. Following this introduction the rest of the paper is divided into the following sections. Section 2 is literature review, section 3 is methodology of the study, section 4 is data analysis and presentation of result and section 5 is conclusion and policy recommendations.

\section{Literature Review}

Bank is a multifaceted concept, it has been argued in the literature that no single definition would suffice for what bank and banking are. For instance, the Bill of Exchange Act of 1882 of Nigeria defines a bank as an institution which carries on the business of banking and banking business; includes lending, acceptance of deposit and collection of cheques and order for payment. According to the study [18] 
affirmed that the definition of what constitutes a bank differs in every country. In Nigeria the Banking Act of 1969, defines banking as the business of receiving monies from outside source as deposit irrespective of payment of interest and granting of money loans and acceptance of credits or purchase of bills and cheques or the purchase and sales of securities for account of other or the marrying of obligation to acquire claims in respect of loan prior to their maturity or the assumption of guarantees and other warranties for order effecting transfer and clearing and such other transactions as the commission may on the recommendation of the designated as banking business".

Banking constitutes the nerve centre of a nation's economic development, one cannot extricate the two terms between bank development and economic development. Bank development and economic development correlate, coexist and cooperate with bank acting as financial intermediary. And so, as a financial intermediary, it mobilizes funds from the surplus sectors of the economy and channels same to the deficit sectors of the economy. Banks thus increase the quantum of national savings and investment conventional of financial intermediation, banks perform such other auxiliary services as financial advisory service, foreign exchange dealing, domestic and international payment and others.

Banking reforms are viewed as government intervention in the banking industry to provide a panacea for existing anomalies in the banking sector. Countries reform their banking sectors for a number of reasons, including structural, capitalization and ownership issues [19]. Most importantly, banking reforms are geared towards financial development in all ramifications and this would inevitably boost economic performance. According to the study [20] banking reforms involve several elements that are unique to each country based on historical, economic and institutional imperatives. Banking reforms are implemented to enhance the intermediation role of banks. The reforms ensure that banks are well positioned to greatly mobilize savings and optimally allocate these mobilized savings in form of credit to profitable investments. These investments are of cognizance to the development process of a nation as provided in the framework of the dual-gap analysis.

The study [21] represented financial reforms, as "deliberate policy response to correct perceived or impending financial crises and subsequent failure. Reforms in the financial industry are aimed at addressing issues such as governance, risk management and operational inefficiencies. The vortex of most financial reforms is around firming up capitalization. The author [20] stated that reforms are predicated upon the need for reorientation and reposition of existing status quo in order to attain an effective and efficient state. Specifically, financial reforms are primarily driven by the need to achieve the objective of consolidation, competition and convergence in the financial architecture [22]. The author [23] examined the extent to which the banking sector meets consolidation objective using post development approach and noted that the process of recapitalization and the consequent merger and or acquisition engendered many of the banks to get registered with the Nigerian Stock Exchange (NSE) and therefore get listed (publicly quoted). According to him ownership of the banks became widened and public are made. The reforms has made many Nigerian to own some stakes in the banking sector rather than private ownership that were the pictures of many banks in the pre consolidation era.

The theoretical foundation of economic reform is vast and spread across the entire spectrum of the neo-classical school of thought. Since the 1980s, African countries have embarked on aggressive economic reforms in an attempt to stimulate and sustain economic growth. According to the author [24] this strategy is in consonance with the neo-classical theory, which asserts that a liberalized (free market) economy is more efficient than a controlled economy. The free market economy option is premised on the principles of macroeconomic stability, trade openness, a reduced role of government and implementation of poverty reducing strategies. In order for free market to have its impact on economic development objectives, economic reform should spread across the spectrum of all the sectors of the economy including the banking sector. Various academic researchers have examined the effect of banking reforms on economic growth with varying dimensions. Their empirical studies are reviewed to provide evidence.

The author [25] investigated the contributions of banking sector to economic growth of Pakistan. The data used in this study were collected from the period of 1981 to 2010. Augmented Dickey Fuller (ADF) and Philip Perron unit root test, ordinary least square and granger causality test was used as econometric techniques. The regression results indicate that deposits, investments, advances, profitability and interest earnings have significant positive impact on economic growth while the Granger-Causality test confirms the bidirectional causal relationship of deposits, advances and profitability with economic growth. On the other side we found unidirectional causal relationship of investments and interest earnings with economic growth runs from investments and interest earnings to economic growth and recommended that the policy makers should make policies to enhance the banking sector in Pakistan because banking sector is significantly contributing in the economic growth of Pakistan.

The author [26] observed that banking sector reform is to achieve a sound, stable, reliable, effective and efficient financial system and this has not been feasible in the Nigerian banking system as a result of the incessant crises in the system. In view of this, they carry out study to address issues in economic development through banking sector in Nigeria. In doing this banking sector reforms were proxied by credit to private sector, financial deepening and money supply and economic development issues considered are unemployment rate, inflation rate and poverty level. It is revealed that in Nigeria, banking sector reforms have made significant impact in addressing some economic development issues such as unemployment rate, and poverty level. 
Specifically, money supply is found to be effective in the addressing unemployment issue than credit to private sector and financial deepening. The author [12] investigates the banking reform in Nigeria of the perspective of Soludo's by using the data of 40 commercial and merchants bank variables used for the study are lending, interest rate and the foreign exchange policy. The study uses the descriptive statistics to test the hypothesis. Hence results indicates that recapitalization has shown significance to reform the banking services and to the growth of economy as whole. Hence the study suggested that a procedure to implement in which interest rate should be operate through monetary policy in order to move the GDP growth continuously toward the unique price and single market for local and international markets.

The author [27] discovers that Nigerian economy has witnessed continuous and extensive structural reforms. Many of the reforms have affected the financial structure and the country's economic performance. He identifies some of the challenges bedeviled with management of financial institution in sustaining economic performance. These are poor asset and liability management, unprofessional behaviour of bank owners and managers, excess liquidity, growth of non bank financial institutions, persistent fiscal deficit, unstable political environment and vulnerability to systemic risks. In conclusion, the author suggested that the challenges of management of Nigeria financial system could be tackled through appropriate legal framework, corporate governance and robust portfolio approach to sustain economic performance.

The author [28] argued that economic problems in Nigeria mirror deep concern considering the avalanche of strategies and measures reflecting various thoughts implemented to achieve development. The authors stress that recapitalization directive in 2005 by the central Bank of Nigeria has resulted into mergers and acquisitions. The study looked into merger and acquisition as capitalization option and banks reconsolidation experience in Nigeria. The study explores secondary data and adopted descriptive-cum- comparative analytical method. Finding of the study reveals that poor performance of financial sector particularly the banking system in sustaining economic performance in Nigeria may not be unconnected with the low capitalization of the sector and the expectation of the emerging mega banks to impact positively on economic performance.

The author [13] investigated the effect of banking sector reforms on economic growth in Nigeria over the period 1999 to 2009. Using the ordinary least square regression technique, it was established that interest rate margins, parallel market premiums, total banking sector credit to private sector, inflation rate, inflation rate lagged by one year, size of banking sector capital and cash reserve ratio account for a very high proportion of the variation in economic growth. Except total banking sector capital, other exogenous variables revealed wrong signs with economic growth. The author [29] conducted a study to determine whether financial sector reforms lead to financial development in multiple countries. Their findings demonstrated a positive impact of banking reforms on economic growth especially in those countries where institutional environment was conducive.

The study [30] investigate the impact of the banking sector reforms on the level of economic growth in Nigeria. The study covered the period 1980 and 2012. The cointegration technique was applied. The result shows that the credit to the private sector which is a key banking sector reform indicator has not significantly influenced the level of economic growth in Nigeria. The result shows that minimum capital base and the level of financial deepening has a positive and significant impact on the level of economic growth in Nigeria and recommended that future reforms in the banking sector should be geared towards credit provision to the private sector.

In the same vain, the author [4] evaluates the relationship between banking sector reforms and performance of Nigerian economy using data spanning (1998-2013) and analyzed using Vector Error Correction Model (VECM). The study reveals that there is also a long-run equilibrium relationship between banking sector reforms and performance of Nigerian economy and the result confirms that there is causality between banking sector reforms and performance of Nigerian economy. The study recommended that, the monetary authorities should be more proactive in bank supervision and pursue a supervisory framework based on prudence and professionalism. Furthermore, the study [14] assessed the impacts of banking sector reforms on the development of the financial sector and growth of the economy over the period 1970-2010. Using econometric technique of OLS revealed that the overall banking reforms have not been able to improve the indices of the banking sector in order to trigger development in the financial sector and growth of the economy. The result also revealed that liberalization of the interest rate which is one of the key elements of the reform was still found weak in stimulating development in the financial sector and growth of the economy.

The author [31] investigated the impact of bank recapitalisation on bank performance using the Ordinary Least Square (OLS) regression analysis. The results showed that bank capitalization has no significant effect on bank profitability and asset quality, whereas liquidity and financial deepening were significantly influenced by the recapitalization. The study concluded that profits maximization drives of Nigerian banks have had counterproductive effect on bank capitalization and efforts of banks to maintain quality assets and remain in business normally erode their capital. Also strategies to increasing bank capitalization can be used to boost loans and advances to the productive sector of the economy.

The author [32] noted that Since 2004, the Central Bank of Nigeria $(\mathrm{CBN})$ has embarked on several intensive banking sector reforms to strengthen the hitherto weak and fragmented banking sector to adequately perform its essential intermediately functions. They examined the implications of the reforms on sectoral credit allocations and economic growth, using both analytical and ordinary least squares 
estimating techniques. They found that despite the drastic reduction in the number of commercial banks during the reform period, credit allocated to the activity sectors (agriculture, mining and quarrying, manufacturing, communication, and oil and gas) improved.

The author [33] investigated the impact of commercial bank credit accessibility and sectoral output performance in Nigerian economy for the period which spanned between 1986 and 2010. An augmented growth model was estimated via the Ordinary Least Square (OLS) techniques to ascertain the relationship between various commercial bank credits and sectoral output growth. The variables were tested for stationarity and co-integration analysis was also carried out using the Augmented Dickey-Fuller test. Also error correction test was performed. The study found that the various commercial bank credit supply and other included variables has a long run relationship with sectoral output performance i.e agricultural, manufacturing and services sector output and the main demand for credit facility in Nigeria is the manufacturing sector. The study also reveal that commercial bank credit has direct and insignificant impact on sectoral output performance but cumulative supply and demand for credit in the previous period has direct and significant impact on the growth of agriculture, manufacturing and the services sectors output. This was attributed to the vital importance of credit facility as an input in the production process and persistent inflow to the manufacturing, Agriculture and services sectors have the capacity to induce the growth and development of the sectors. The study concluded that continuous credit accessibility in a deregulated financial market economy has the capacity to induced the nation sectoral output performance which will promote economic growth and development when adequate monetary and fiscal policy are put in place to encourage the demand and supply of commercial bank credit to the real sector of the economy.

The author [34] examined the impact of bank domestic credits on the economic growth of Nigeria. Using time series on Nigerian data for the period 1980-2013, credit to private sector, credit to government sector and contingent liability were used as proxy for bank domestic credit while gross domestic product represents economic growth. The relative statistics of the estimated model shows that credit to the private sector (CPS) and Credit to the government sector (CGS) positively and significantly correlate with GDP in the short run. The analysis revealed the existence of poor long run relationship between bank domestic credit indicators and gross domestic product in Nigeria. They recommended the managers of the Nigeria economy should fashion out appropriate policies that will enhance the bi-directional flow of influence between the banking sector where investable funds are sourced and the real sector of the economy where goods and services are produced, and there should be efficient and effective utilization of borrowed funds in order to achieve the nominated objective of investment, productivity and economic growth.

\section{Research Method}

\subsection{Theoretical Framework}

The theoretical bases for this study is derived from the classical work of the authors $[35,36]$ who presented the first systematic attempt at taking into account some of the specific characteristics that impair the performance of financial system in developing countries. They argued that the financial sector in most developing economies is repressed by series of government interventions that have the effect of keeping the interest rate low or negative. The repression takes different forms, such as ceiling of interest rate, imposition of trade restriction and barriers to free movement of goods and services across countries as well as imposition of larger reserves and liquidity requirements. In addition to these, there are restrictions that constraint banks to engage in certain types of lending and prohibit them from acquiring some financial assets.

According to Mckinnon and Shaw theory, the effect of this repression would inevitably be adverse on investment and growth of the economy. Central to the argument of the studies $[35,36]$ is the idea of financial sector liberalization. The author [37] posited that financial liberation involves the elimination of credit controls, deregulation of interest rate, development of capital markets, proper regulation and supervision and liberation of international capital flow. In the case of Nigeria, the financial sector was under serious repression which led to the Central Bank of Nigeria (CBN) to embark on financial sector reformed between 1986 and 2004 through the Structural Adjustment Programme (SAP). The idea was to allow the market to determine the rate of interest and increase the competitiveness of banks in the country. The effect of the reformed was to enable the financial sector facilitate among other things, the growth of the Nigeria's economy.

\subsection{Model Specification}

In this study, the studies $[12,13]$ were adopted. The study employs reduced form behavioral model within a partial equilibrium framework for the level of economic growth determined by bank sector reforms. The model is specified thus:

$$
\mathrm{RGDP}=\mathrm{f}(\mathrm{M} 1 / \mathrm{M} 2, \mathrm{CPS}, \mathrm{LDR}, \mathrm{CRR}, \mathrm{INT})
$$

In a behavoural form, we have

$$
\begin{aligned}
\mathrm{RGDP}= & \beta 0+\beta 1 \mathrm{M} 1 / \mathrm{M} 2+\beta 2 \mathrm{CPS}+\beta 3 \mathrm{LDR}+ \\
& \beta 4 \mathrm{CRR}+\beta 5 \mathrm{INT}+\mathrm{Ut}
\end{aligned}
$$

Where

RGDP $=$ Real Gross Domestic Product

$\mathrm{M}_{1} / \mathrm{M}_{2}=$ Ratio of Narrow Money to Broad Money

$\mathrm{CPS}=$ Commercial Bank Credit to the Private Sector

LDR $=$ Loan Deposit Ratio

$\mathrm{CRR}=$ Cash Reserve Ratio

INT $=$ Interest Rate Proxied by Prime Lending Rate 


\subsection{Sources of Data Analysis}

The data used in carry out this study is time series data for the period 1970 - 2014 obtained mainly from secondary sources. Among these are Central Bank of Nigeria (CBN) statistical bulletin (various issues), The National Bureau of Statistic (NBS), Economic Journals, text book and published article in the subject matter.

\subsection{Techniques of Data Analysis}

The study adopts the bounds testing cointegration procedure to estimate the long run and short run relationships and dynamic interaction among the variables of interest. The author [38] proposed the Autoregressive Distributed Lag (ARDL) bounds testing approach to investigating the existence of cointegration relationship among variables. The choice of this modeling approach is based on the following considerations. First, it circumvents the problem of the order of integration associated with the Johansen likelihood approach [39]. Second, unlike most of the conventional multivariate cointegration procedures, which are valid for large sample size, the bounds test approach is suitable for small sample size study [38] Third, it provides unbiased estimates of the long run model and valid t-statistics even when some of the regressors are endogenous [40]. Fourth, the bound test does not impose a restrictive assumption that all variables under study must be integrated of the same order. Also, it is unnecessary that the order of integration of the underlying regressors be ascertained prior to testing the existence of a level relationship between the variables [38]. However, to ensure that the variables are not integrated of higher order 1(2), it may be useful to test the unit root. Fifth, it estimates the short and long run components of the model simultaneously, removing problems of omitted variables and autocorrection. The following ARDL model is estimated in order to test the cointegration relationship between the variables. The Autoregressive Distributed Lag (ARDL) specification of equation 3 above is presented below as equation 4 .

$$
\begin{gathered}
\Delta \ln (R G D P)_{t}=\alpha_{0}+\sum_{i-1}^{p} \propto_{1} \Delta \ln (R G D P)_{t-i}+\sum_{i-0}^{p} \propto_{2} \Delta \ln \left(\frac{\frac{M 1}{M 2}}{{ }^{2}}\right)_{t-i}+\sum_{i-0}^{p} \propto_{3} \Delta \ln (C P S)_{t-i}+\sum_{i-0}^{p} \propto_{4} \Delta \ln (L D R)_{t-i}+ \\
\sum_{i-0}^{p} \propto_{5} \Delta \ln (C R R)_{t-i}+\sum_{i-1}^{p} \propto_{6} \Delta \ln (I N T)_{t-i}+\delta \ln (R G D P)_{t-i}+\delta \ln (M 1 / M 2)_{t-i}+\delta \ln (C P S)_{t-i}+\delta \ln (L D R)_{t-i}+ \\
\delta \ln (C R R)_{t-i}+\delta \ln (I N T)_{t-i}+v_{i}
\end{gathered}
$$

Where $\delta \mathrm{i}$ is the long run multipliers, $\alpha_{0}$ is the intercept and $v_{t}$ are white noise errors. The first step in the ARDL bounds testing approach is to estimate equation (3) by Ordinary Least Squares (OLS) in order to test for the existence of a long run relationship among the variables by conducting an F-test for the joint significance of the coefficients of the lagged levels of the variables, that is: $H_{0}: \alpha_{1}=\alpha_{2}=\alpha_{3}=\alpha_{4}=\alpha_{5}$ $=0$ against the alternative $\mathrm{H}_{1}: \alpha_{1} \neq \alpha_{2} \neq \alpha_{3} \neq \alpha_{4} \neq \alpha_{5} \neq 0$ We denote the test which normalize on by RGDP (RGDP|M1/M2, CPS, LDR, CRR, INT).

Two asymptotic critical value bounds provide a test for cointegration when the independent variables are I(d) [where
$0 \leq \mathrm{d} \leq 1]$ : a lower value assuming the regressors are $\mathrm{I}(0)$ and an upper value assuming purely I(1) regressors. If the Fstatistic is above the upper critical value, the null hypothesis of no long run relationship can be rejected irrespective of the orders of integration for the time series. Conversely, if the test statistic falls below the lower critical value, the null hypothesis cannot be rejected. Finally, if the statistic falls between the lower and upper critical values, the result is inconclusive. The approximate critical values for the Fstatistic test were obtained from [38]. Once cointegration is established the conditional ARDL $\left(\alpha_{1}, \alpha_{2}, \alpha_{3}, \alpha_{4}, \alpha_{5}\right)$ long run model for $\mathrm{RDGP}_{\mathrm{t}}$ can be estimated as:

$$
\begin{gathered}
\Delta \ln (R G D P)_{t}=\alpha_{0}+\sum_{i=1}^{p} \alpha_{1} \Delta \ln (R G D P)_{t-i}+\sum_{i-0}^{p} \propto_{2} \Delta \ln \left(\frac{\frac{M 1}{M 2}}{\frac{}{M 2}}\right)_{t-i}+\sum_{i-0}^{p} \propto_{3} \Delta \ln (C P S)_{t-i}+\sum_{i-0}^{p} \alpha_{4} \Delta \ln (L D R)_{t-i}+ \\
\sum_{i-0}^{p} \propto_{5} \Delta \ln (C R R)_{t-i}+\sum_{i-1}^{p} \propto_{6} \Delta \ln (I N T)_{t-i}+v_{i}
\end{gathered}
$$

This involves selecting the orders of the ARDL $\left(\alpha_{1}, \alpha_{2}, \alpha_{3}, \alpha_{4}, \alpha_{5}\right)$ model in the five variables using Aikaike Information Criteria (AIC). The next step is to obtain the short run dynamic parameters by estimating an error correction model associated with the long run estimates. This is specified as:

$$
\begin{gathered}
\Delta \ln (R G D P)_{t}=\alpha_{0}+\sum_{i-1}^{p} \propto_{1} \Delta \ln (R G D P)_{t-i}+\sum_{i-0}^{p} \propto_{2} \Delta \ln \left(\frac{\underline{\underline{M 1}}}{M 2}\right)_{t-i}+\sum_{i-0}^{p} \propto_{3} \Delta \ln (C P S)_{t-i}+\sum_{i-0}^{p} \propto_{4} \Delta \ln (L D R)_{t-i}+ \\
\sum_{i-0}^{p} \propto_{5} \Delta \ln (C R R)_{t-i}+\sum_{i-1}^{p} \propto_{6} \Delta \ln (I N T)_{t-i}+\beta e c m_{t-1}+v_{i}
\end{gathered}
$$

All coefficients of short-run equations are coefficients relating to the short run dynamics of the model's convergence to equilibrium and $\beta$ represent the speed of adjustment and ECM is the Error Correction term that is 
derived from the estimated equilibrium relation of equation (5).

The lag length selection criteria will also be determined to know the number of lag to include in the estimation. We estimate the equations in three stages. First, we estimate the pre bank reforms period (1970-1985). Second, we estimate the reforms period 1986-2014) and lastly, we estimate entire period (1970-2014).

\section{Discussion of Results}

\subsection{Unit Root Test}

Prior to the testing of ARDL bound test, we conducted a test of order of integration for each variable using Augmented Dickey-Fuller (ADF). The Unit Root Test could convince us whether or not the ARDL model should be used. The result of the ADF unit root test is presented in table 1 below:

Table 1. Augmented - Dickey Fuller (ADF) Test Result.

\begin{tabular}{lllll}
\hline Variable & ADF calculated value at Level & ADF calculated value at 1st Difference & McKinnon 5\% Critical value & Order of Integration \\
\hline LCPS & -0.7847 & -5.3445 & -2.9314 & $1(1)$ \\
LCRR & -1.3396 & -5.3859 & -2.9314 & $1(1)$ \\
LDR & -3.0018 & - & -2.9297 & $1(0)$ \\
LINT & -1.6911 & -6.3896 & -2.9314 & $1(1)$ \\
LM1_M2 & -1.7865 & -7.1505 & -2.9314 & $1(1)$ \\
LRGDP & -0.7318 & -5.6473 & -2.9314 & $1(1)$ \\
\hline
\end{tabular}

Source: Author's Regression Output

From the table 1, real gross domestic product, ratio of narrow money to broad money, commercial bank credit to the private sector, cash reserve ratio and interest rate are stationary at first difference 1(1) since the ADF value of each of the variables at first difference is greater than the McKinnon 5\% critical values while loan deposit ratio is stationary at level 1(0). Therefore, unit test show that there is a mixture of $\mathrm{I}(1)$ and $\mathrm{I}(0)$ of underlying regressors and therefore, the ARDL testing could proceed.

\subsection{Lag Length Criteria}

The step that follows is, therefore, determining the appropriate lag. The lag-length selection criteria such as sequential modified LR test statistic (LR), Final Prediction
Error (FPE), Akaike Information Criterion (AIC), Schwarz Information Criterion (SC), and Hanna-Quinn information criterion (HQ) were employed to determine the appropriate lag length of pre bank reforms model, bank reforms model and the pool model. The test results of the different lag selection methods are reported in table 2, 3 and 4. After a meticulous examination of the different lag lengths by estimating the VAR at each lag length and diagnosing the whiteness of resulting residuals, one (1) lag length, as recommended by Aikaike Information Criteria AIC statistic, was selected for pre bank reforms model, two (2) lag lengths for bank reforms while three lag length was chosen for pool policy model.

Table 2. VAR Lag Order Selection Criteria (Pre Bank Reforms Model).

\begin{tabular}{lllllll}
\hline \multicolumn{2}{l}{ VAR Lag Order Selection Criteria } \\
\hline \multicolumn{2}{l}{ Included observations: 15 } & & & & \\
\hline Lag & LogL & LR & FPE & AIC & SC & HQ \\
\hline 0 & 99.96619 & NA & $1.46 \mathrm{e}-13$ & -12.52883 & -12.24561 & -12.53184 \\
1 & 230.5905 & $139.3326^{*}$ & $7.74 \mathrm{e}-19^{*}$ & $-25.14540^{*}$ & $-23.16286^{*}$ & $-25.16652^{*}$ \\
\hline
\end{tabular}

* indicates lag order selected by the criterion

Source: Author's Regression Output

Table 3. VAR Lag Order Selection Criteria (Bank Reforms Model).

\begin{tabular}{lllllll}
\hline \multicolumn{2}{l}{ VAR Lag Order Selection Criteria } \\
\hline \multicolumn{2}{l}{ Included observations: $\mathbf{1 4 3}$} & \multicolumn{5}{l}{} \\
\hline Lag & LogL & LR & FPE & AIC & SC & HQ \\
\hline 0 & 377.6014 & NA & $1.32 \mathrm{e}-11$ & -5.183236 & -5.038202 & -5.124301 \\
1 & 863.4863 & 917.4051 & $2.94 \mathrm{e}-14$ & -11.29351 & -10.13324 & -10.82203 \\
2 & 1238.292 & $670.9808^{*}$ & $3.10 \mathrm{e}-16^{*}$ & $-15.85024^{*}$ & $-13.67472^{*}$ & $-14.96621^{*}$ \\
\hline
\end{tabular}

* indicates lag order selected by the criterion

Source: Author's Regression Output

Table 4. VAR Lag Order Selection Criteria (Pool Policy model).

\begin{tabular}{lllllll}
\hline \multicolumn{2}{l}{ VAR Lag Order Selection Criteria } \\
\hline \multicolumn{2}{l}{ Included observations: 41 } & & & & & \\
\hline Lag & LogL & LR & FPE & AIC & SC & HQ \\
\hline 0 & -112.5876 & NA & 0.008582 & 9.429812 & 9.913695 & 9.569153 \\
1 & -63.72314 & 71.41722 & 0.001463 & 7.594088 & 9.287679 & 8.081781 \\
\hline
\end{tabular}




\begin{tabular}{lllllll}
\hline \multicolumn{2}{l}{ VAR Lag Order Selection Criteria } \\
\hline \multicolumn{2}{l}{ Included observations: $\mathbf{4 1}$} & & & & \\
\hline Lag & LogL & LR & FPE & AIC & SC & HQ \\
\hline 2 & -27.51447 & 38.99396 & 0.000842 & 6.731882 & 9.635182 & 7.567927 \\
3 & 36.84956 & $44.55971^{*}$ & $0.000101^{*}$ & $3.703880^{*}$ & $7.816888^{*}$ & $4.888277^{*}$ \\
\hline
\end{tabular}

* indicates lag order selected by the criterion

Source: Author's Regression Output

\subsection{Bounds Test for Co-Integration}

The next step after determining the order of integration and lag length of the variables was to apply the bound F-test in order to establish the existences or otherwise of long-run relationship among the variables. The summary results of the bounds test for co-integration for the pre bank reformed (1970-1985), bank reformed (1986-2014) and pool period (1970-2014) in Tables 5 below alongside with critical values.

The computed F-statistic from bound test for pre bank reformed, bank reformed and pool period are 8.1659, 10.5361 and 4.4518 respectively. These values exceed the upper bounds critical value of 3.38 at $5 \%$ significance level. This implies that the alternate hypothesis of the existence of a unique co-integration (long run) relationship between economic growth and bank reforms variables while the null hypothesis of no co-integration is rejected.

Table 5. Summary of ARDL Bound Test Results.

\begin{tabular}{|c|c|c|c|c|c|c|}
\hline \multirow{2}{*}{ Models } & \multirow{2}{*}{ Test statistic } & \multirow{2}{*}{$\begin{array}{l}\text { Computed } \\
\text { F-statistic } \\
\end{array}$} & \multirow{2}{*}{ Lag } & \multirow{2}{*}{ Significance level } & \multicolumn{2}{|c|}{ Bound Critical values } \\
\hline & & & & & Lower Bounds I(0) & Upper Bounds I(1) \\
\hline Pre Bank Reforms (1970-1985) & F-statistic & 8.1659 & 1 & $5 \%$ & 2.39 & 3.38 \\
\hline Bank Reforms (1986-2014) & F-statistic & 10.5361 & 2 & $5 \%$ & 2.39 & 3.38 \\
\hline Pool Period (1970-2014) & F-statistic & 4.4518 & 3 & $5 \%$ & 2.39 & 3.38 \\
\hline
\end{tabular}

Source: Author's Regression Output.

\subsection{Long Run Test Regression Results of Economic Growth}

The results of the estimated long run coefficients using the ARDL approach are presented in Table 6 below. The pre bank reforms (1970-1985), bank reforms (1986-2014) and pool period (1970-2014) model are selected by AIC are $(1,1,1,1.1 .1),(1,1$, $0,2,0,1)$ and $(1,0,3,3,2,3)$.

Table 6. Summary of the Long Run ARDL Regression Results.

\begin{tabular}{llll}
\hline \multirow{2}{*}{ Independent Variable } & Pre Bank Reforms Model (1970-1985) & Bank Reforms Model (1986-2014) & Pool Period Model (1970-2014) \\
\cline { 2 - 4 } & $\begin{array}{l}\text { Dependent Variable } \\
\text { LRGDP }\end{array}$ & $\begin{array}{l}\text { Dependent Variable } \\
\text { LRGDP }\end{array}$ & $\begin{array}{l}\text { Dependent Variable } \\
\text { LRGDP }\end{array}$ \\
\hline Constant & $-8.6944(-1.7653)$ & $1.2532(0.5017)$ & $10.9953(1.7840)$ \\
LM1/M2 & $6.3034^{*}(2.4826)$ & $-1.4501(-0.1350)$ & $1.4384(0.7732)$ \\
LCPS & $0.4693^{*}(3.9772)$ & $0.7628^{*}(16.0478)$ & $0.8845^{*}(13.2683)$ \\
LLDR & $-1.8228^{*}(-3.3489)$ & $-0.5279(-0.4621)$ & $-5.8173 *(-2.4345)$ \\
LCRR & $-0.1319(2.0644)$ & $0.2655(1.6790)$ & $-0.8213 *(-2.0622)$ \\
LINT & $3.3667(2.2859)$ & $0.3655^{*}(0.5241)$ & $0.1277(0.2995)$ \\
\hline
\end{tabular}

The values in paratenses are t-statistic

Note: * is significant at 5\% level of significance.

Source $=$ Author Regression output

From Table 6 above, it could be observed that the entire variable during the bank pre reforms period met their expected sign except interest rate and cash reserve ratio, the ratio of narrow money to broad money (LM1/M2) has direct and insignificant impact on Nigeria economic growth. One percent increase in LM1/M2 leads to 6.3034 percent increase in Nigeria's economic growth. This is inconsistent with apriori expectation. This result supports the fact that in the long run during pre bank reforms increase in ratio of narrow money to broad money does not enhanced the growth performance of the Nigerian economy which implies that increase in payment facility retard the growth of the Nigerian economy during pre bank reforms period. The result further revealed that credit to the private sector (LCPS) has direct and significant impact on the growth of the Nigeria economy. One percent increase in LCPS lead to about 0.4693 percent increase in economic growth during the pre bank reforms period. This is consistent with the apriori expectation. This finding indicates that credit to the private sector if properly channeled to productive sectors leads to economic growth in the country. This is inline with Balago (2014) who noted that bank credit to the private sector has direct and significant effect on economic growth.

The result of loan deposit ratio (LDR) has inverse and significant impact on Nigeria economic growth such that one percent increase in LDR leads to 1.8228 percent decrease in economic growth but cash reserve ratio (LCRR) has direct and insignificant impact on Nigeria economic growth such 
that one percent increase in LCRR lead to 0.3949 percent decrease in economic growth during the pre bank reforms period. This is not consistent with the apriori expectation.

The coefficient of interest rate (LINT) has direct but insignificant impact on Nigeria economic growth. One percent increase in LINT lead to 3.3667 percent increase in economic growth. This is not consistent with the apriori expectation. The insignificant nature of this variable is as a result of poor interest rate policy and the dominance of formal sector in granting credit facilities to the Nigerian economy during the pre bank reforms on the long run.

From Table 6 above, it could be observed that the entire variable in bank reforms period met their expected sign except interest rate and ratio of narrow money to broad money. Also, the ratio of narrow money to broad money (LM1/M2) has inverse and insignificant impact on Nigeria economic growth. One percent increase in LM1/M2 leads to 1.4501 percent decrease in Nigeria's economic growth. This is not consistent with apriori expectation. This result supports the fact that on the long run increase in ratio of narrow money to broad money does not enhanced the growth performance of the Nigerian economy which implies that increase in payment facility does not aid economic performance. The result further revealed that credit to the private sector (LCPS) has direct and significant impact on the growth of the Nigeria economy. One percent increase in LCPS lead to about 0.7628 percent increase in economic growth during bank reforms period. This is consistent with the apriori expectation. This finding indicates that credit to the private sector has a robust impact on the productive sectors which have a spillover effect on Nigeria economic growth. This result conform to Sesugh (2013) finings that there is statistical significance between Credit to Private Sector and Real Gross Domestic Product proxied for economic growth and concluded that The Nigerian banking sector should increase the amount of credit given to private sector; this will in turn contributes greatly to the growth of the Nigerian economy.

This result of loan deposit ratio (LDR) has inverse and insignificant impact on Nigeria economic growth such that one percent increase in LDR leads to 0.5279 percent decrease in economic growth but cash reserve ratio (CRR) has direct and insignificant impact on Nigeria economic growth such that one percent increase in CRR lead to 0.2655 percent increase in economic growth during the bank reforms period. This is inconsistent with the apriori expectation. The coefficient of interest rate (LINT) has direct but insignificant impact on Nigeria economic growth. One percent increase in LINT lead to 0.3655 percent increase in economic growth.
This is not consistent with the apriori expectation. The insignificant nature of this variable is as a result of the dominance of informal sector in granting credit facilities to the Nigerian economy on the long run.

From Table 6 above, it could be observed that the entire variable during the pool period which comprises of pre bank and bank reformed period met their expected sign except interest rate. Also, the ratio of narrow money to broad money (LM1/M2) has direct and insignificant impact on Nigeria economic growth. One percent increase in LM1/M2 leads to 1.4501 percent increase in Nigeria's economic growth. This is inconsistent with apriori expectation. This result supports the fact that in the long run during both pre and reformed period increase in ratio of narrow money to broad money does not enhanced the growth performance of the Nigerian economy which implies that increase in payment facility retard the growth of the Nigerian economy during the period of study which does not aid economic growth. The result further revealed that credit to the private sector (LCPS) has direct and significant impact on the growth of the Nigeria economy. One percent increase in LCPS lead to about 0.8844 percent increase in economic growth during the pool period. This is consistent with the apriori expectation. This finding indicates that credit to the private sector if properly channeled to productive sectors leads to economic growth in the country.

The result of loan deposit ratio (LDR) has inverse and significant impact on Nigeria economic growth such that one percent increase in LDR leads to 5.8173 percent decrease on economic growth also cash reserve ratio (LCRR) has direct and significant impact on Nigeria economic growth such that one percent increase in LCRR lead to 0.8213 percent decrease in economic growth during the period. This is not consistent with the apriori expectation.

The coefficient of interest rate (LINT) has direct but insignificant impact on Nigeria economic growth. One percent increase in LINT lead to 0.1277 percent increase in economic growth. This is not consistent with the apriori expectation. The insignificant nature of this variable is as a result of poor interest rate policy and the dominance of formal sector in granting credit facilities to the Nigerian economy on the long run.

\subsection{Short Run Parsimonious Estimation of Economic Growth}

In order to capture the short run deviations that might have occurred in estimating the long run co-integration equation, a dynamic parsimonious error correction estimate is reported in Table 7:

Table 7. Summary of Short Run Parsimonious Estimations.

\begin{tabular}{llll}
\hline \multirow{2}{*}{$\begin{array}{l}\text { Independent } \\
\text { Variables }\end{array}$} & Pre Bank Reforms Model (1970-1985) & Bank Reforms Model (1986-2014) & Pool Period Model (1970-2014) \\
\cline { 2 - 4 } & $\begin{array}{l}\text { Dependent Variable } \\
\text { LRGDP }\end{array}$ & $\begin{array}{l}\text { Dependent Variable } \\
\text { LRGDP }\end{array}$ & $\begin{array}{l}\text { Dependent Variable } \\
\text { LRGDP }\end{array}$ \\
\hline D(LM1/M2) & $-6.6156^{*}(14.6942)$ & $0.4986(1.4421)$ & $0.6327^{*}(1.5413)$ \\
D(LLCPS) & $2.2665^{*}(17.0132)$ & $0.3132 *(2.7463)$ & $0.3226(1.3850)$ \\
D(LCPS(-1)) & & & $0.7387 *(3.0425)$ \\
D(LCPS(-2) $)$ & & & $0.5475^{*}(2.4098)$ \\
\hline
\end{tabular}




\begin{tabular}{llll}
\hline $\begin{array}{l}\text { Independent } \\
\text { Variables }\end{array}$ & Pre Bank Reforms Model (1970-1985) & Bank Reforms Model (1986-2014) & Pool Period Model (1970-2014) \\
\cline { 2 - 4 } & $\begin{array}{l}\text { Dependent Variable } \\
\text { LRGDP }\end{array}$ & $\begin{array}{l}\text { Dependent Variable } \\
\text { LRGDP }\end{array}$ & $\begin{array}{l}\text { Dependent Variable } \\
\text { LRGDP }\end{array}$ \\
\hline D(LLDR) & $-5.2878^{*}(-2.800)$ & $-0.4421(-1.9851)$ & $0.3580(-1.4311)$ \\
D(LLDR(-1)) & & $0.4130 *(2.3463)$ & $0.6143 *(-2.7048)$ \\
D(LLDR(-2)) & & & $0.3840(1.7730)$ \\
D(LCRR) & $-0.1319(-4.7198)$ & $-0.0628(-0.8256)$ & $0.0699(1.1542)$ \\
D(LCRR(-1)) & & & $1.599(1.8221)$ \\
D(LINT) & $2.3482 *(11.0177)$ & $-0.1394(-1.0179)$ & $-0.1170(-0.8556)$ \\
D(INT(-1)) & & & $-0.5099 *(-3.1388)$ \\
D(INT(-2)) & & $-0.3518 *(-2.2618)$ & $-0.4283 *(-2.3455)$ \\
ECM(-1) & $-0.4749 *(-2.7792)$ & $-0.4184 *(-5.2513)$ & $-0.4033 *(-6.1819)$ \\
\hline
\end{tabular}

The values in paratenses are t-statistic

Note: * is significant at $5 \%$ level of significance.

Source: Authors Regression output.

Table 7 indicates that during the pre bank reforms model ratio of narrow money to broad money (M1/M2), commercial bank credit to private sector (CPS), Loan deposit ratio (LLDR), Cash reserves ratio (CRR) and interest rate (LINT) has a significant impact on Nigeria economic growth. However, LM1/M2, LLDR and LCRR have inverse effect on Nigeria economic growth. This implies that during the pre bank reforms LM1/M2, LLDR and LCRR have not impacted on the growth of the Nigerian economy. The coefficient of $\operatorname{ECM}(-1)$ for pre bank reforms is statistically significant at $5 \%$ level. This confirms the existence of a long run relationship between the variables. The coefficient of ECM term is -0.4749 . This indicates that about 47 percent disequilibria in the growth of the Nigerian economy in the previous one year are corrected in the current year. The significance of the ECM is an indication and a confirmation of the existence of a long run equilibrium relationship between the economic growth and bank performance indicators during the pre bank reforms period.

The estimation of bank reformed model show that narrow money to broad money (M1/M2) has direct and insignificant impact on Nigeria economic growth. The coefficient of credit to commercial bank to private sector of D(LCPS) has direct and significant effect on Nigeria economic growth. This implies that continuous increase in credit supply to the real sector has the tendency to induce the performance of the sector on the short run.

The difference in loan deposit ratio $\mathrm{D}(\mathrm{LLDR})$ has inverse and insignificant impact on the Nigerian economy on the short run but $\mathrm{D}(\operatorname{LLDR}(-1))$ has direct and significant effect on the growth of the Nigerian economy. This implies that adequate loan deposit ratio in the previous period enhance economic growth. The difference in cash reserves ratio (CRR) has direct but insignificance to the growth economy. The result revealed that the difference in interest rate $\mathrm{D}(\mathrm{INT})$ has inverse and insignificant impact on the Nigerian economy on the short run during the reformed period but $\mathrm{D}(\mathrm{INT}(-1))$ has inverse and significant effect on the growth of the Nigerian economy. This implies that well managed interest enhances the performance of the economy.

The coefficient of $\operatorname{ECM}(-1)$ for bank reformed model is found to be statistically significant at 5\% level. This confirms the existence of a long run relationship between the variables. The coefficient of ECM term is -0.4184 . This indicates that about 42 percent disequilibria in the Nigeria economic growth in the previous one year are corrected in the current year. The significance of the ECM is an indication and a confirmation of the existence of a long run equilibrium relationship between Nigeria economic growth and indicators of bank during the bank reforms period.

Table 7 indicate that the estimation of the pool period of the difference in ratio of narrow money to broad money D(M1/M2) has direct but insignificant impact on Nigeria's economic growth. The estimation of the difference in commercial bank credit to private sector during the pool period D(LCPS), D(LCPS(-1)) and D(LCPS(-2)) have direct and significant impact on Nigeria's economic growth on the short run during the pool period.

The coefficients of difference in loan deposit ratio D(LLDR) has inverse but insignificant impact on Nigeria economic growth. This is consistent with apriori expectation but at lag one and two $\mathrm{D}(\operatorname{LLDR}(-1))$ and $\mathrm{D}(\operatorname{LLDR}(-2))$ have direct and significant impact on Nigeria's economic growth. This implies that continuous increase in loan deposit ratio will enable bank to met investors loan demand which have a spillover effect on the economy. The cash reserves ratio at lag one and two $\mathrm{D}(\mathrm{LCRR})$ and $\mathrm{D}(\operatorname{LCRR}(-1))$ has direct and insignificant impact on Nigeria economic growth on the short run. The estimation of the coefficients of difference in interest rate $\mathrm{D}(\mathrm{LINT}), \mathrm{D}(\operatorname{LINT}(-1))$ and $\mathrm{D}(\operatorname{LCBM}(-2))$, are all statistically significant and have inverse impact on the Nigeria economic growth.

The coefficient of $\operatorname{ECM}(-1)$ for the pool period is found to be statistically significant at $5 \%$ level. This confirms the existence of a long run relationship between the variables. The coefficient of ECM term is -0.4033 . This indicates that about 40 percent disequilibria in the growth of the Nigerian economy in the previous one year are corrected in the current year. The significance of the ECM is an indication and a confirmation of the existence of a long run equilibrium relationship between economic growth and indicators of bank performance. 


\subsection{Diagnostic Test}

To confirm the robustness of the model, a diagnostic test was performed as shown in table 8:

Table 8. Key Regression Statistics.

\begin{tabular}{llll}
\hline Key Regression & Pre Bank Reforms (1970-1985) Model & Bank Reforms (1986-2014) Model & Pool Period (1970-2014) Model \\
\hline R-squared & 0.7662 & 0.5442 & 0.9152 \\
Adjusted R-squared & 0.6232 & 0.4828 & 0.8336 \\
F-statistic & 6.9254 & 4.6099 & 30.9374 \\
Prob.(F-statistic) & 0.0389 & 0.0162 & 0.0000 \\
Durbin - Watson stat & 1.9622 & 1.8576 & 2.0401 \\
\hline
\end{tabular}

Sources: Author Regression Output

From Table 6 above, the coefficient of determinations $\mathrm{R}^{2}$ of pre bank reformed model estimation is 0.7662 which indicates that about 77 percent of the total variations in Nigeria economic growth are explained by the pre bank reforms variables. The F-statistic shows overall significance of the model. The F-statistic is significant at 5\% level. The probability of its value $(0.0389)$ is less than the 0.05 critical levels. We, therefore, reject the null hypothesis that the model is not significant in explaining the variations in the growth of the Nigerian economy. Finally, The Durbin Watson statistic value is 1.9622 . This test value shows the absence of positive serial autocorrelation among the independent variables since the DW statistics is approximately 2 .

The coefficient of determinations $\mathrm{R}^{2}$ of bank reforms model estimation is 0.5446 which indicates that about 54 percent of the total variation in Nigeria's economic growth is explained by the variations in the bank reformed variables. The F-statistic shows overall significance of the model. The F-statistic is significant at 5\% level. The probability of its value $(0.0162)$ is less than the 0.05 critical levels. We, therefore, reject the null hypothesis that the model is not significant in explaining the variations in the growth of the Nigerian economy. Finally, The Durbin Watson statistic value is 1.8576 . This test value shows absence of positive serial autocorrelation among the independent variables since the DW statistics is approximately 2 .

Furthermore, the coefficient of determinations $\mathrm{R}^{2}$ of pool period model is 0.9153 which indicates that about 92 percent of the total variations in Nigeria's economic growth are explained by the variations in the pool policies variables. The F-statistic shows overall significance of the model. The Fstatistic is significant at $5 \%$ level. The probability of its value 0.0000 is less than the 0.05 critical levels. We, therefore, reject the null hypothesis that the model is not significant in explaining the variations in the Nigeria economic growth. Finally, The Durbin Watson statistic value is 2.0402. This test value shows the absence of positive serial autocorrelation among the independent variables since the DW statistics is approximately 2 . This makes the estimation suitable for policy formulation.

Conclusively, the bank reforms has not impacted on the growth of the Nigerian economy since the coefficient of determination of the pre reforms model is greater than the reforms model (76>54). This finding is consistent with [16] that the key banking sector reform indicator has not significantly influenced the level of economic growth in Nigeria. Also [17] in their study of the impact of banking sector reforms on the performance of Nigerian Economy using structural value, the study revealed that the banking sector reforms have not really improve the performance of the Nigerian Economy. Furthermore, [14] and [15] Within this framework, found that the overall banking reforms have not been able to improve the indices of the banking sector in order to trigger development in the financial sector and growth of the Nigerian economy.

\subsection{Stability Test}

Stability test was also performed using Cumulative Sum (CUSUM) and Cumulative Sum of Square (CUSUM Q) of residual of the ARDL model of pre bank reforms model, bank reforms model and the pool period model are shown in appendix 2, 3, and 4. The existence of parameter instability is established if the Cumulative Sum of the residual goes outside the area between the critical (dotted bounded) lines. It is estimated at 5 percent critical level. From appendix 2, 3, and 4 it can be inferred that the bank reforms model and the pool period model at 5 percent level of significance has been stable over time while pre bank reforms is unstable as a results of the poor policy to drive the banking sector.

\section{Conclusion and Recommendations}

This study examined the impact of bank sector reforms on Nigeria's economics growth for the period which spanned from 1970 to 2014 . The period was disaggregated into pre bank reforms period (1970-1985), reforms period (1986-2014) and pool period (1970-2014). In order to achieve the objective of the study, an econometric model was formulated. Real Gross domestic product (GDP) was used as a proxy for economic growth regressed on some bank performance variables such as ratio of narrow money to broad money, loan deposit ratio, commercial bank credit to the private sector, cash reserve ratio and interest rate. These variables were included in our econometric model based on review of related literature. Data were collected from secondary sources and analysis with ARDL bounds testing approach to co-integration analysis popularised by [38] to establish the long run relationship 
between the relevant time series variables. The study shown that on the long run, loan deposit ratio and commercial bank credit to the private sector have a significant impact on Nigeria economic growth while cash reserve ratio, ratio of narrow money to broad money and interest rate have insignificant impact on Nigeria economic growth during the pre reforms period. Also on the short run all the variables have a significant impact on Nigeria economic growth. Also commercial bank credit to the private sector has a significant impact on Nigeria economic growth while loan deposit ratio, cash reserve ratio, ratio of narrow money to broad money and interest rate have insignificant impact on Nigeria economic growth during the reforms period. Also on the short run all the variables except ratio of narrow money to broad money has insignificant impact on Nigeria economic growth. Conclusively, the bank reformed has not impacted on the growth of the Nigerian economy since the coefficient of determination of the pre reformed model is greater than the reformed period $(76>54)$. This finding is consistent with [16, 17, 14] and [15] who reported that the key banking sector reform indicators has not significantly influenced the level of economic growth in Nigeria. Therefore, to further enhance the performance of the banking sector and its positive contributions to economic growth in Nigeria, the following recommendations have been proffered.

1. Government should ensure strict regulatory measures through the use of its monetary policies to regulate the banking sector. The Central Bank of Nigeria, through the use of its credit control instruments should regulate the interest rates to enable the private sector borrow at a moderate rate thereby enhancing investment, which in turn leads to economic growth.

2. The achievement of financial sector stability is fundamental to the maintenance of macroeconomic stability, which is sine qua non for sustainable growth and development. Therefore, the monetary authorities and other financial institutions should be strengthened in their regulatory frame work and capacity to maintain financial stability and bank sector reforms

3. The regulatory and supervisory framework should be further strengthened, healthy competition promoted among banks and interest rate policy should be made to stimulate investors to borrow and participate in productive activities which have a spillover effect on Nigeria economic growth.

4. The Central Bank of Nigeria should continue with its banking sector reforms and encourage substantial credit allocation to the prioritized private sector. This will help to promote employment generation and economic growth.

5. Regulatory bodies should put in place periodic monitoring to ensure compliance with bank reforms code of corporate governance. Stress test on banks by the $\mathrm{CBN}$ should be more frequent and periodic.

\section{References}

[1] Darrat, A. F., Chopin, M. C., \& Lobo, B. J. (2005). Money and macroeconomic performance: revisiting divisia money. Review of Financial Economics, 14 (2), 93-101.

[2] Adeleye, N., Osabuohien, E., Bowale, E., Matthew, O., \& Oduntan, E. (2018). Financial reforms and credit growth in Nigeria: empirical insights from ARDL and ECM techniques. International Review of Applied Economics, 32 (6), 807-820.

[3] Todaro, M. P., \& Smith, S. C. (2009). Economic development. Edinburgh Gate, HarlowEngland: Pearson Education Limited.

[4] Ikeora, J. J. E. P., Igbodika, M. N. P., \& Andabai, P. W. (2016). Banking sector reforms and the performance of Nigerian economy: A vector error correction investigation (VECM). European Journal of Research and Reflection in Management Sciences, 4 (2).

[5] Nzotta, S. M. (2014). Money, Banking and Finance: Theory and Practice. Revised Edition, Hudson-jude. Owerri.

[6] Soludo, C. C. (2004). Consolidating the Nigerian banking industry to meet the development challenges of the $21 \mathrm{st}$ century. In Being an address delivered to the Special Meeting of the Bankers' Committee, held on July (6).

[7] Mbaeri, C. C., \& Adioha, N. (2015). Bank reform and economic growth In Nigeria. International Journal for Innovation Education and Research, 3 (5).

[8] Ningi, S. I., \& Dutse, A. Y. (2008). Impact of bank consolidation strategy on the Nigerian economy. African Economic and Business Review, 6 (2), 26-45.

[9] Okpara, G. C. (2011). Bank reforms and the performance of the Nigerian banking sector: An empirical analysis. International Journal of Current Research, 2 (1), 142-153.

[10] Somoye, R. O. C. (2008). The performances of commercial banks in post-consolidation period in Nigeria: An empirical review. European Journal of Economics, Finance and Administrative Sciences, 14 (14), 62-73.

[11] CBN (2014). Statistical Bulletin. Central Bank of Nigeria.

[12] Dele, C. A. (2007). Principles of Finance, Lagos, Page Publishers.

[13] Fadare, S. O. (2010). Recent banking sector reforms and economic growth in Nigeria. Middle Eastern Finance and Economics, 8 (8), 146-160.

[14] Essien, A. (2012). An Assessment of the Impacts of Banking Sector Reforms in Nigeria. Available at SSRN 2189820.

[15] Azeez, B. A., \& Oke, M. O. (2012). A Time Series Analysis on the Effect of Banking Reforms on Nigeria's Economic Growth. International Journ. Econ. Res, 3 (4), 26-37.

[16] Abiodun, E. \& Oriavwote, V. E (2014). An Empirical Assessment of Banking Sector Reform and Unemployment in Nigeria, International Journal of Business, Humanities and Technology, 4 (1), 107-125.

[17] Ogunsakin, S. (2014), Nigerian financial sector and manufacturing industries. Journal of Applied Chemistry, 7 (3), 41-46. 
[18] Gardener, E. P., \& Molyneux, P. (Eds.). (1990). Changes in western European banking (Vol. 6). Taylor \& Francis.

[19] Ogbunuka, U. M. (2005). Banking Sector Reforms and Bank Consolidation: The Experience of Turkey. CBN Bullion, 29 (2).

[20] Ajayi, M. (2005). Banking sector reforms and bank consolidation: Conceptual framework. CBN bullion, 29 (2), 210 .

[21] Ebong, B. B. (2006). Banking sector reforms: Opportunities and challenges. Union Digest-An Economic and Business Publication of Union Bank of Nigeria Plc, 10 (1), 1-9.

[22] Deccan, H. (2004). New Banking reforms to focus on Consolidation. New Delhi: DHNs.

[23] Idowu, E. (2014). Is Increasing Bank Capital the Solution to Improving Bank Liquidity and Preventing Bank Distress in Nigeria?. Universal Journal of Applied Science, 2 (4), 83-91.

[24] Magbagbeola, N. O. (2004). Theoretical and Conceptual Issues in Economic Reforms. Paper presented at the 2004 CBN Executive Policy Seminar.

[25] Aurangzeb, K. A. (2012). Contributions of banking sector in economic growth: A case of Pakistan. Economics and Finance Review, 2 (6), 45-54.

[26] Uzomba, P. C., Chukwu, S. N., Jumbo, G. A. and Nwankwo, N. U. (2014). An Inquiring into the Impact of Deposit Money Banks' Loans/Advances on Agricultural Sector in Nigeria; 1980 - 2011. International Review of Social Sciences and Humanities, 7 (2), 130-139.

[27] Tella, A. (2006) Financial Sector Reforms and Management of Financial Institutions in Nigeria: Challenges and Prospects. 1st International Conference 15th - 17th March 2006 Olabisi Onabanjo University Ago-Iwoye Ogun State Nigeria.

[28] Akingunola R. O. \& Adegoke J. F. (2006) Bank Recapitalization and Merger as a Financial Reform Strategy for Sustainable Economic Growth in Nigeria. 1st International Conference 15th - 17th March 2006 Olabisi Onabanjo University Ago-Iwoye Ogun State Nigeria.

[29] Tressel, T., \& Detragiache, E. (2008). Do financial sector reforms lead to financial development? Evidence from a new dataset (No. 2008-2265). International Monetary Fund.
[30] Adelegan, A. E., \& Oriavwote, V. (2014). An Empirical Analysis of Nigeria's Experience with Banking Sector Reforms, International Journal of Economics, Business and Finance, 2 (1), 1-12.

[31] Bernard, A., \& Michael, C. O. (2014). Nigerian bank recapitalisation reforms: Effect on the banks and the economy (2000-2012). Int. J. Manag. Stud. Res, 2 (2), 48-56.

[32] Akpansung, A. O., \& Gidigbi, M. O. (2014). Recent Banking Reforms in Nigeria: Implications on Sectoral Credit Allocation and Economic Growth, International Journal of Business and Social Science, 5 (3): 91-104.

[33] Ehikioya, I., \& Mohammed, I. (2013). Commercial bank credit accessibility and sectoral output performance in a deregulated financial market economy: empirical evidence from Nigeria. Journal of Finance and Bank Management, 1 (2), 36-59.

[34] Iwedi, M., Igbanibo, D. S., \& Onuegbu, O. (2015). Bank domestic credits and economic growth nexus in Nigeria (1980-2013). Int J Finance Accounting, 4 (5), 236-244.

[35] McKinnon, T. I. (1973). Money and capital in economic development. Brookings Institution Press.

[36] Shaw, E. S. (1973). Financial deepening in economic development.

[37] Orok-Duke, O. E., Ekott, G. A., \& Edu, B. E. (2009). Critical Review of Financial Sector Reforms and Financial Liberalization in Developing Countries [A Practical Discussion in Nigerian Context]. Available at SSRN 1483477.

[38] Pesaran, M. H., Shin, Y., \& Smith, R. J. (2001). Bounds testing approaches to the analysis of level relationships. Journal of applied econometrics, 16 (3), 289-326.

[39] Johansen, S., \& Juselius, K. (1990). Maximum likelihood estimation and inference on cointegration - with applications to the demand for money. Oxford Bulletin of Economics and statistics, 52 (2), 169-210.

[40] Harris, R., \& Sollis, R. (2003). Applied time series modelling and forecasting. 